\title{
The Major Outer Membrane Protein MopB Is Required for Twitching Movement and Affects Biofilm Formation and Virulence in Two Xylella fastidiosa strains
}

\author{
Hongyu Chen, ${ }^{1}$ Prem P. Kandel, ${ }^{1}$ Luisa F. Cruz, ${ }^{1}$ Paul A. Cobine, ${ }^{2}$ and Leonardo De La Fuente ${ }^{1,+}$ \\ ${ }^{1}$ Department of Entomology and Plant Pathology, Auburn University, Auburn, AL 36849, U.S.A.; and ${ }^{2}$ Department of Biological \\ Sciences, Auburn University
}

Accepted 11 August 2017.

\begin{abstract}
MopB is a major outer membrane protein (OMP) in Xylella fastidiosa, a bacterial plant pathogen that causes losses on many economically important crops. Based on in silico analysis, the uncharacterized MopB protein of $X$. fastidiosa contains a $\beta$-barrel structure with an OmpA-like domain and a predicted calcium-binding motif. Here, MopB function was studied by mutational analysis taking advantage of the natural competence of $X$. fastidiosa. Mutants of $m o p B$ were constructed in two different $X$. fastidiosa strains, the type strain Temecula and the more virulent WM1-1. Deletion of the mopB gene impaired cell-to-cell aggregation, surface attachment, and biofilm formation in both strains. Interestingly, mopB deletion completely abolished twitching motility. Electron microscopy of the bacterial cell surface revealed that mopB deletion eliminated type IV and type I pili formation, potentially caused by destabilization of the outer membrane. Both mopB mutants showed reduced virulence using tobacco (Nicotiana tabacum) as a host under greenhouse conditions. These results suggest that MopB has pleiotropic functions in biofilm formation and twitching motility and is important for virulence of $X$. fastidiosa.
\end{abstract}

Xylella fastidiosa is a gram-negative plant-pathogenic bacterium that causes many economically important diseases, including Pierce's disease (PD) in grapevine and citrus variegated chlorosis (Almeida and Nunney 2015; Bae et al. 2015). The pathogen is transmitted by xylem sap-feeding insects such as sharpshooters, leafhoppers, and spittlebugs, by directly injecting the bacterium into xylem vessels (Almeida et al. 2003; Chatterjee et al. 2008). The bacterium strictly colonizes the xylem vessels (Chatterjee et al. 2008) and, therefore, is difficult to control, due to the challenge of common antibacterial treatments reaching the pathogen. Currently there are no effective long-term practices to control the devastating diseases caused by $X$. fastidiosa.

Current address for Luisa F. Cruz: Tropical Research and Education Center, University of Florida, Institute of Food and Agricultural Sciences, 18905 S.W. 280 Street, Homestead, FL 33031, U.S.A.

${ }^{\dagger}$ Corresponding author: Leonardo De La Fuente;

E-mail: 1zd0005@auburn.edu

*The $\boldsymbol{e}$-Xtra logo stands for "electronic extra" and indicates that two supplementary figures and a supplementary video are published online.

(c) 2017 The American Phytopathological Society
The virulence mechanisms of $X$. fastidiosa are not entirely understood. The current working hypothesis is that disease symptoms caused by $X$. fastidiosa infection are the result of long term water deficit, which is associated with the blockage of xylem vessels by bacterial biofilms and plant-produced gels and tyloses (Chatterjee et al. 2008; Sun et al. 2013). Biofilm formed by different pathogens is vital for its persistence in a nutrient-poor plant xylem system (Castiblanco and Sundin 2015). Additionally, for systemic colonization of the plant xylem system, upstream migration is important, which is mediated by type IV pilus-driven twitching motility (Meng et al. 2005). Therefore, twitching motility and biofilm formation are critical virulence traits of $X$. fastidiosa. Previous studies showed that two regulatory genes, $\operatorname{alg} U$ and $x h p T$, which encode proteins with roles in environmental stress response and regulation of cell-cell aggregation and biofilm formation, are important for virulence (Shi et al. 2007; Voegel et al. 2013). Other factors implicated in virulence include secreted proteins (Nascimento et al. 2016; Zhang et al. 2015), such as a functional polygalacturonase encoded by pglA (Roper et al. 2007) and a lipase encoded by lesA (Nascimento et al. 2016).

Previous studies from our group indicated that mineral elements in the xylem, such as zinc ( $\mathrm{Zn})$ and calcium $(\mathrm{Ca})$, can affect traits associated with virulence of $X$. fastidiosa. Zn was shown to be a stress factor with pleiotropic effects on $X$. fastidiosa, decreasing growth and biofilm formation of the bacterium but increasing exopolysaccharide production and adhesion strength of biofilms (Navarrete and De La Fuente 2014). Ca was found to increase cell attachment, biofilm formation, and twitching motility of $X$. fastidiosa (Cruz et al. 2012). Ca was also found to accumulate at higher concentrations in biofilm than in planktonic cells (Cobine et al. 2013). Ca is a divalent cation that can function as an ion bridge between bacterial cells as well as between bacterial cells and xylem surfaces (Leite et al. 2002). However, previous research by our group found that disrupting de novo protein synthesis abolishes the Ca-induced increase in surface attachment by $X$. fastidiosa. (Cruz et al. 2012). This research suggested a regulatory effect of $\mathrm{Ca}$ on $X$. fastidiosa virulence traits. Ca also interacts with a particular homolog of PilY1, a type IV pilus structural protein that contains a $\mathrm{Ca}-$ binding motif, enhancing twitching motility of $X$. fastidiosa (Cruz et al. 2014). Recently, whole transcriptome analyses conducted by our group indicated that gene expression of biofilm cells is broadly modified by $\mathrm{Ca}$ supplementation (Parker et al. 2016). These results suggest multiple regulatory roles for Ca in X. fastidiosa.

Proteins in the outer membrane of gram-negative bacteria have many functions, such as serving as transporters, recognizing 
proteins and components of signal transduction cascades, and maintaining integrity of this structure (Koebnik et al. 2000). In $X$. fastidiosa, the outer membrane protein (OMP) MopB (PD1709) has been used as a recognition target in an engineered antimicrobial therapeutics approach for protection against $X$. fastidiosa (Dandekar et al. 2012). MopB is required for pathogenicity in Xanthomonas campestris pv. campestris, the causal agent of black rot in crucifers (Chen et al. 2010), but its role in virulence of $X$. fastidiosa has not been studied.

In this study, mopB mutants in two $X$. fastidiosa wild-type (WT) strains, Temecula and WM1-1, were constructed by sitedirected mutagenesis. Temecula is the type strain for PD in grapevine, and its whole genome has been sequenced (Van Sluys et al. 2003). WM1-1 is an aggressive strain that our research group isolated from naturally-infected grapevines in Georgia (Oliver et al. 2014; Parker et al. 2012). The response of the mutants to $\mathrm{Ca}$ supplementation and its effect on adhesiveness, biofilm formation, twitching motility, and disease development in planta were evaluated.

\section{RESULTS}

In silico analysis of the MopB homolog (PD1709) of $X$. fastidiosa.

The 1,170-bp open reading frame of PD1709 in the $X$. fastidiosa Temecula genome was identified as the homo$\log$ of Xanthomonas campestris pv. campestris MopB protein (100\% coverage and $70 \%$ similarity). PD1709 was the only MopB homolog found in the Temecula genome and the other $X$. fastidiosa genomes available at the National Center for Biotechnology Information (NCBI). The N-terminal domain of MopB forms an antiparallel $\beta$ barrel, which is predicted to be embedded in the outer membrane, and the C-terminal half has an OmpA domain located in the periplasmic space. This predicted structure is very similar to proteins in the OmpA family (Supplementary Fig. S1). In addition, a putative EF-hand motif, $\mathrm{Dx}[\mathrm{DN}] \mathrm{xDxxxxx}[\mathrm{DE}]$, is located in the C-terminal half of the protein (Parker et al. 2016).

\section{Generation of mopB knockout mutants} of $X$. fastidiosa Temecula and WM1-1.

Taking advantage of natural competence of $X$. fastidios $a$, the vector pJET_mopB_Kan was introduced into X. fastidiosa Temecula and WM1-1, generating mopB knockout mutants in both strains. Mutation was confirmed by the absence of the mор $B$ gene and insertion of a kanamycin-resistance cassette in the торB locus (Supplementary Fig. S2A). In addition, sequencing of the regions upstream and downstream of mopB confirmed that insertion of the kanamycin cassette did not modify adjacent genes (data not shown).

Crude extracts of proteins of WT strains and mopB mutants were separated by sodium dodecyl sulfate-polyacrylamide (SDS-PAGE) gel electrophoresis. A major protein band of approximately $42 \mathrm{kDa}$ was detected in WT strains but not in $m o p B$ mutants. This major protein band was excised from the gel, was digested, and was subjected to identification by liquid chromatography-tandem mass spectrometry (LC-MS/MS). The top hit in the analysis (using the Global Proteome Machine) was the MopB homolog in X. fastidiosa 9a5c (due to available sequences in database), with 10 peptides identified with $14 \%$ coverage out of a maximum expected coverage of $19 \%$ and a $\log (\mathrm{e})$ of -27.8 that reflects the probability of randomly assigning this protein with this dataset. Therefore, the major band was $X$. fastidiosa MopB.

\section{Effect of mopB mutation on planktonic growth and biofilm formation of $X$. fastidiosa.}

To characterize mopB mutants of $X$. fastidiosa, the effect of these mutations on planktonic growth and biofilm formation was evaluated. When grown in PD2 broth, similar planktonic growth was observed between the mopB mutant and its isogenic WT strain (Fig. 1A). Similar results were observed when all the strains were grown in $4 \mathrm{mM}$ Ca-supplemented PD2 broth (4Ca) (Fig. 1B).

In 96-well plate assays, biofilm formation of each strain was quantified at 7 days postinoculation (dpi). In all the culture media tested (PD2, 4Ca, 50\% 'Chardonnay' xylem fluid [50\% Sap], and 'Chardonnay' xylem fluid [Sap]), biofilm formed by mopB mutants was significantly less $(P<0.05)$ than the corresponding WT strains (Fig. 1C). In the three media containing higher $\mathrm{Ca}$ concentration than $\mathrm{PD} 2$, biofilm growth of each strain was significantly increased $(P<0.05)$.

\section{MopB is important for cell aggregation and surface attachment.}

Surface attachment and cell aggregation are initial stages in the process of biofilm formation (Castiblanco and Sundin 2015). The strength of surface attachment was assessed by measuring the percentage of attached cells and calculating the adhesion force for Temecula and mopB(T), using microfluidic chambers. When the flow rate was higher than $40 \mu \mathrm{min}^{-1}$, the percentage of attached $\operatorname{mop} B(\mathrm{~T})$ cells decreased dramatically when compared with WT Temecula cells (Fig. 2A). A significant reduction in adhesion force $(P=0.02)$ was observed for $\operatorname{mop} B(\mathrm{~T})$
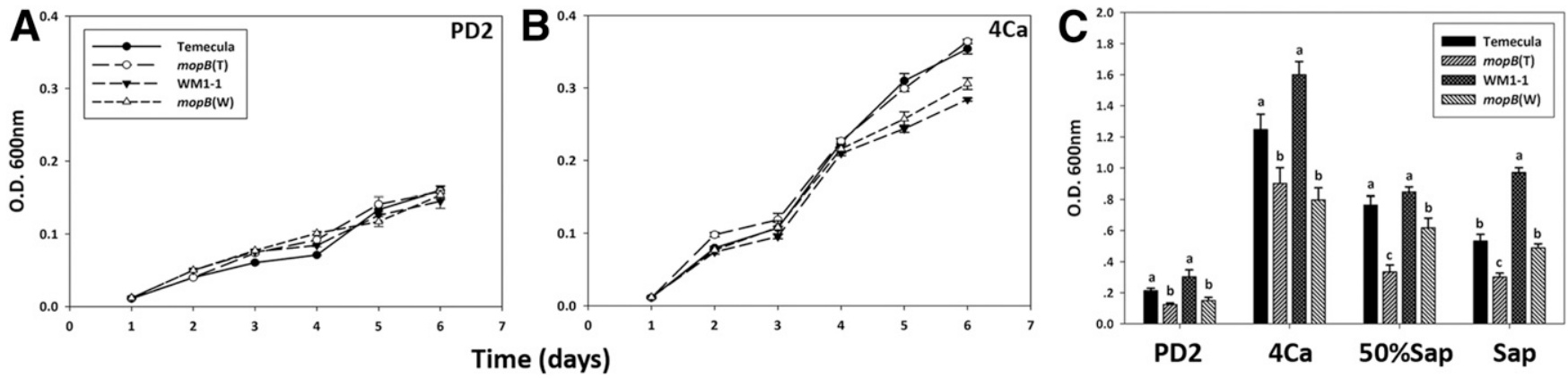

Fig. 1. Planktonic growth and biofilm formation of Xylella fastidiosa strains under different Ca concentration. A and B, Planktonic growth curve of $X$. fastidiosa wild type (WT) strains and mopB mutants in 96-well plates containing PD2 broth (PD2) and PD2 broth supplemented with 4 mM CaCl 2 (4Ca) for 7 days. C, Biofilm quantification of WT strains and mopB mutants cultured in 96-well plates for 7 days. PD2, 4Ca, 50\%Sap, and Sap represent PD2 broth, PD2 broth supplemented with $4 \mathrm{mM} \mathrm{CaCl} 2,50 \%$ 'Chardonnay' grape xylem fluid, and $100 \%$ 'Chardonnay' grape xylem fluid. Each data point represents means $(n=12)$ and standard error of the mean from one representative experiment. Three independent experiments were performed under the same conditions. Different letters indicate significant differences $(P<0.05)$ of biofilm formation among $X$. fastidiosa strains, according to the GLIMMIX procedure using SAS 9.4 (SAS Institute Inc.). 
$(139.4 \pm 29.9 \mathrm{pN})$ compared with Temecula $(221.8 \pm 24.4 \mathrm{pN})$, as shown in Figure 2B.

Cell aggregation of Temecula and $\operatorname{mop} B(\mathrm{~T})$ were observed in microfluidic chambers (Fig. 2C). At 5 dpi, aggregates of Temecula cells were observed in several sections of the microchannel. In contrast, aggregates of $\operatorname{mop} B(\mathrm{~T})$ cells were rarely observed and the size of the aggregates was much smaller than that of Temecula. Additionally, cell aggregation of the two WT strains and their corresponding mutants was quantified by calculating the relative percentage of aggregated cells in 50-ml conical tubes (Fig. 2D). Percentage of aggregated cells of mopB mutants was significantly lower $(P<0.001)$ than that of the WT stains in PD2. However, in $4 \mathrm{Ca}$, there was no significant difference between the WT and mutant strains.

\section{mopB mutants are nonmotile.}

Colony fringe width on agar plates is a parameter used to measure twitching motility of $X$. fastidiosa. WT strains and mopB mutants on periwinkle wilt (PW) and $\mathrm{PW}$ agar plates supplemented with $2 \mathrm{mM}$ Ca were used to measure colony fringe. In all conditions, peripheral fringe was detected for WT Temecula and WM1-1 (Fig. 3A) but the edge of mopB mutant colonies was smooth and there was no visible peripheral fringe (Fig. 3A). On the PW plate, the width of the fringe in WM1-1 (mean $=49.78 \pm 1.78 \mu \mathrm{m})$ was significantly higher than that of Temecula $($ mean $=26.71 \pm 1.02 \mu \mathrm{m})(P<0.001)($ Fig. 3B). In $2 \mathrm{mM}$ Ca-supplemented PW plates, fringe width of both WT strains was increased (Fig. 3C) and the difference between WM $1-1($ mean $=84.45 \pm 2.63 \mu \mathrm{m})$ and Temecula $($ mean $=45.08 \pm$ $2.62 \mu \mathrm{m})$ was still significant $(P<0.001)$.
In microfluidic chambers, the twitching movement of single cells was visible (Supplementary Video S1). Temecula cells inside channels of the microfluidic chambers not only moved with the medium flow but, also, moved against the flow direction. In contrast, the upstream movement of $\operatorname{mop} B(\mathrm{~T})$ cells was not observed. The average twitching speed of Temecula cells was $0.45 \mu \mathrm{m} \mathrm{min}{ }^{-1}$ (Fig. 3D). Results obtained from microfluidic chamber experiments confirmed colony fringe observations. Transmission electron micrographs revealed the presence of pili on one pole of the WT $X$. fastidiosa strains (Fig. 4), as previously described (Meng et al. 2005). In contrast, no type I and type IV pili were observed in either of the mopB mutants (Fig. 4).

\section{mopB mutation causes a decrease in virulence in both $X$. fastidiosa wild-type strains.}

Previous reports showed that tobacco is a suitable model plant for studying virulence of $X$. fastidiosa and investigating $X$. fastidiosa-host interactions (De La Fuente et al. 2013; Francis et al. 2008; Oliver et al. 2014). 'Petite Havana SR1' tobacco plants inoculated with the WT $X$. fastidiosa strains showed symptoms including leaf scorch and leaf curling. The earliest symptoms were observed in the WT-inoculated plants approximately 70 to $75 \mathrm{dpi}$. One or two weeks later, symptoms were visible on the $m o p B(\mathrm{~W})$ - and $m o p B(\mathrm{~T})$-inoculated plants (Fig. $5 \mathrm{~A})$. During monitoring of symptoms for 4 weeks, the disease incidence of plants inoculated with the WT strains was always higher than that of the plants inoculated with the mopB mutants (Fig. 5A). The mutation also affected severity of symptoms in leaves (Fig. 5B). At 90 to 95 dpi, leaf-scorch symptoms were
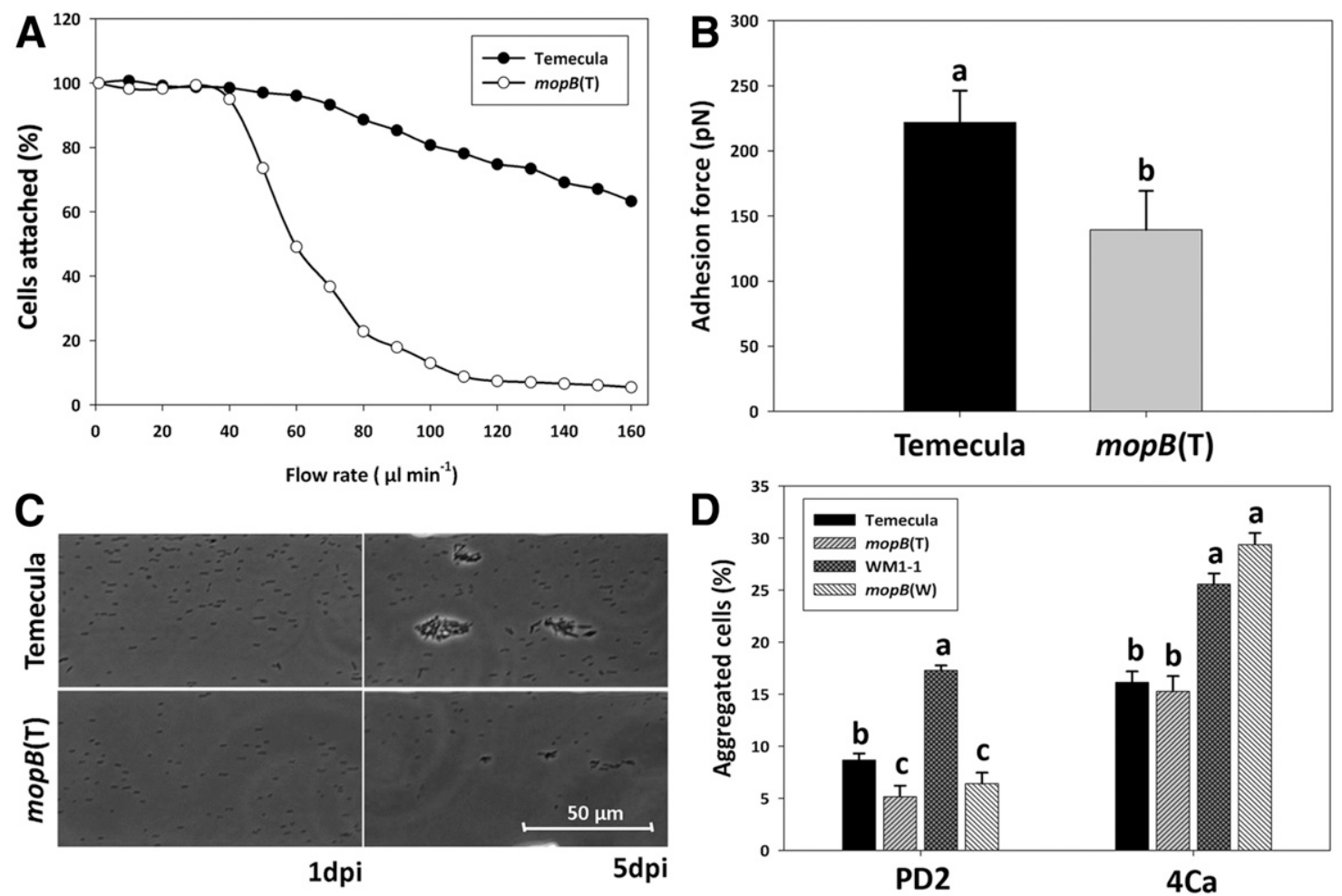

Fig. 2. Evaluation of cell aggregation and surface attachment of Xylella fastidiosa wild type (WT) and mopB mutants. A, Cell surface attachment inside microfluidic chambers as a function of increased medium flow rate. The data represented in the graph corresponds to one representative experiment. Three independent experiments were performed under the same conditions. B, Adhesion force, measured in piconewtons (pN), of $X$. fastidiosa Temecula and mopB(T) was assessed in microfluidic chambers. Adhesion force refers the amount of force necessary for cell detachment. Data presented was obtained from three independent experiments. Error bars represent standard errors of the mean $(n=3)$. Different letters on top of the bars indicate significant differences $(P<0.05)$ according to a Student's $t$ test. C, Time-lapse micrographs showing formation of cell aggregates inside microfluidic chambers. Images were captured at 1 and 5 days postinoculation (dpi). D, Percentage of aggregated cells grown in 50-ml conical tubes. Each data point represents means $(n=3)$ and standard error of the mean from one representative experiment. Three independent experiments were performed under the same conditions. Different letters on top of the bars indicate significant differences $(P<0.05)$, according to the GLIMMIX procedure using SAS 9.4 (SAS Institute Inc.). 
$40 \%$ fewer in $\operatorname{mopB}(\mathrm{T})$ mutant-inoculated plants, as compared with Temecula-inoculated plants, and 53\% fewer in $\operatorname{mop} B(\mathrm{~W})$ mutant-inoculated plants, as compared with WM11-inoculated plants (Fig. 5C).

\section{Colonization of $X$. fastidiosa in tobacco plants.}

Quantitative polymerase chain reaction (qPCR) detection indicated $100 \%$ of the infected plants were colonized by $X$. fastidiosa. There was no significant difference in bacterial populations in leaf petioles of plants infected by WT strains and mopB mutants at 90 to 95 dpi. For plants infected with Temecula and $\operatorname{mop} B(\mathrm{~T})$, the average bacterial population detected in infected plant leaf petioles was $3.72 \pm 0.22$ and $3.84 \pm 0.26 \log \mathrm{CFU} \mathrm{mg}^{-1}$, respectively. For plants infected with WM1-1 and $\operatorname{mop} B(\mathrm{~W})$, the average bacterial population detected was $3.62 \pm 0.11$

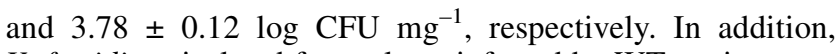
$X$. fastidiosa isolated from plants infected by WT strains grew on PW plates but did not grow on PW plates with $50 \mu \mathrm{g}$ of kanamycin per milliliter, confirming the lack of kanamycin resistance. $X$. fastidiosa isolated from plants infected by mutants not only grew on PW plates but also grew on PW plates with $50 \mu \mathrm{g}$ of kanamycin per milliliter, confirming that these infecting isolates retained the kanamycin resistance cassette inserted in the $m o p B$ locus.

\section{DISCUSSION}

In this study, we have shown that the major OMP MopB has a pleiotropic effect that influences virulence in $X$. fastidiosa. Using two strains of $X$. fastidiosa, deletion of mopB impaired
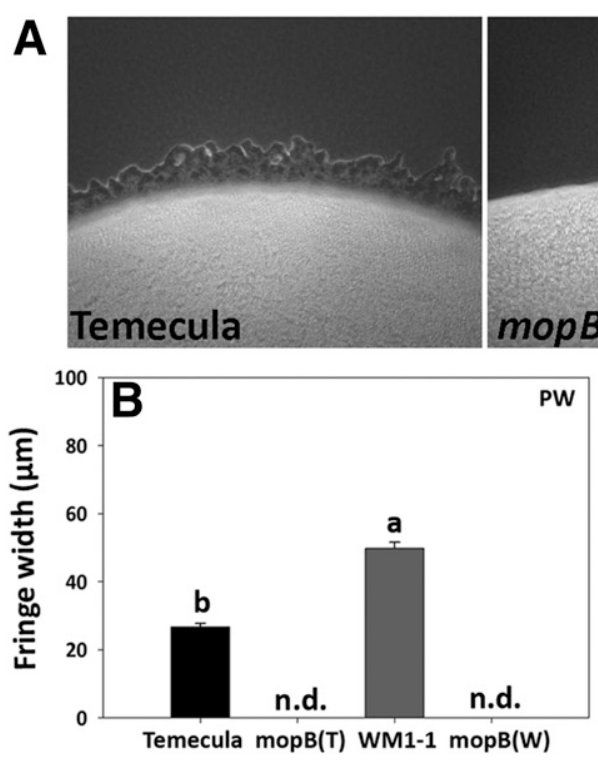
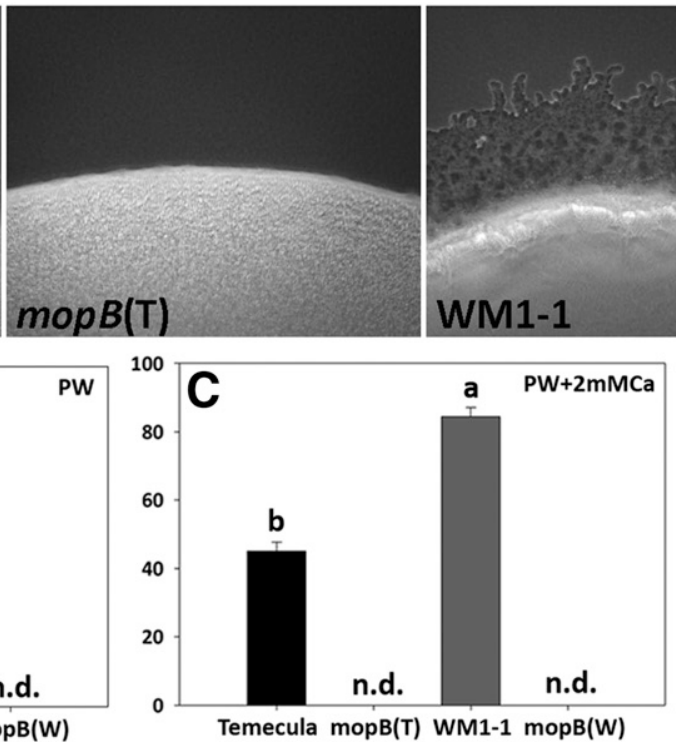
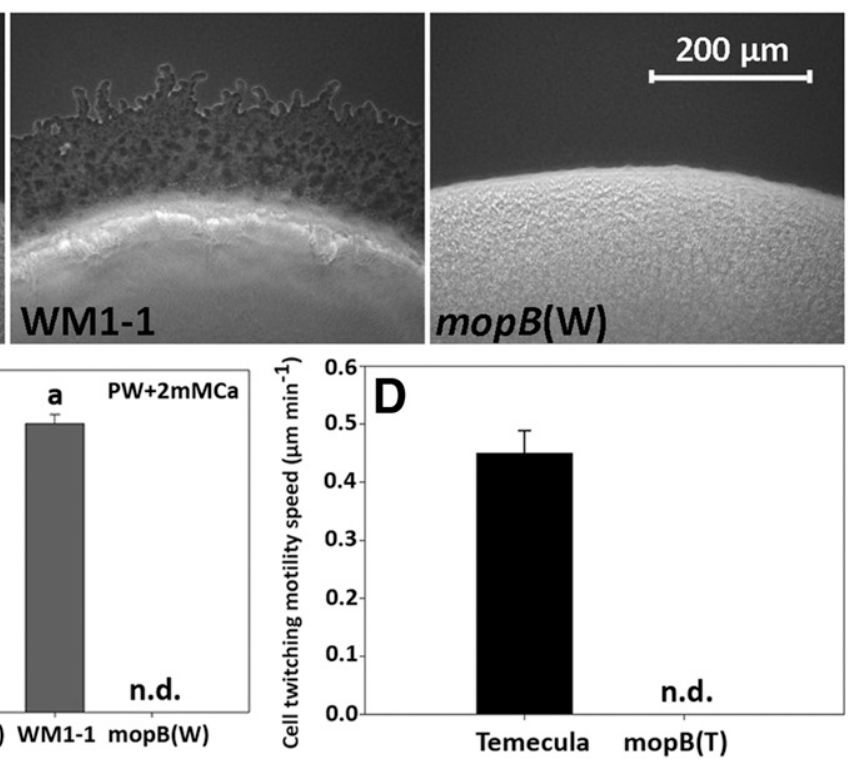

Fig. 3. Twitching motility of Xylella fastidiosa wild-type (WT) strains and mopB mutants. A, Representative micrographs of bacteria colony fringe on periwinkle wilt (PW) plates. B and $\mathbf{C}$, Colony fringe width of $X$. fastidiosa WT strains and mopB mutants on PW plates and PW plates supplemented with $2 \mathrm{mM} \mathrm{CaCl}_{2}$. Each data point represents means $(n=12)$ and standard error (SE) of the mean from one representative experiment. Four independent experiments were performed under the same conditions. Different letters on top of the bars indicate significant differences $(P<0.05)$, according to the GLIMMIX procedure using SAS 9.4 (SAS Institute Inc.). n.d. = not detected. D, Twitching speed assessments of $X$. fastidiosa Temecula and mopB(T) in microfluidic chambers. Different letters on top of the bars indicate significant differences $(P<0.05)$ according to a Student's $t$ test. Data presented was obtained from three independent experiments. Error bars correspond to SE of the mean $(n=9)$.
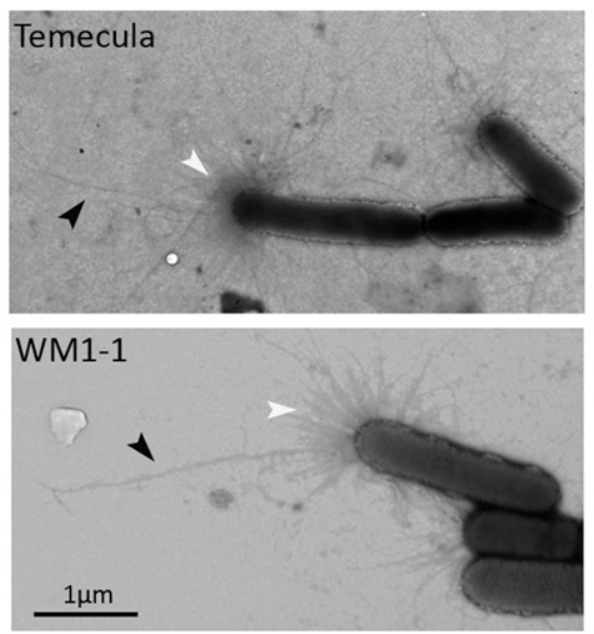
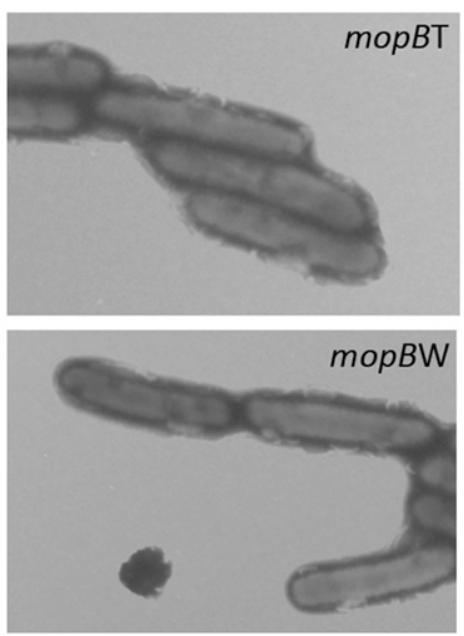

Fig. 4. Transmission electron micrographs of negatively stained cells of Xylella fastidiosa wild type (WT) strains and mopB mutants. White arrows indicate type I pili and black arrows indicate type IV pili on the polar end of WT strains. No pili were observed in any of the mopB mutants. The magnification is $10,000 \times$, images were captured on a Zeiss EM 10 transmission electron microscope. Scale bar on bottom left indicates $1 \mu$ m. 
surface attachment and biofilm formation, abolished twitching motility, and attenuated disease development. Our findings show, for the first time, that MopB is required for bacterial type IV pili biogenesis and twitching motility and contribute to our understanding of the requirements for virulence in $X$. fastidiosa.

In a previous study conducted by our group, $\mathrm{Ca}$ increased surface attachment, biofilm formation, and twitching motility of X. fastidiosa (Cruz et al. 2012). Additionally, in other bacterial species, several studies showed that $\mathrm{Ca}$-binding by proteins containing conserved Ca-binding motifs help regulate biofilm formation (Arrizubieta et al. 2004; Sarkisova et al. 2014). The sequence motif Dx[DN]xDxxxxxx[DE], known as an EF-hand, was found in the C-terminus of $X$. fastidiosa MopB (Parker et al. 2016); therefore, we hypothesized that Ca-binding by the OMP MopB would have an important role in the response to $\mathrm{Ca}$ during biofilm formation by $X$. fastidiosa. We observed that $m о р B$ mutants were significantly impaired in biofilm formation under normal laboratory conditions, and, while biofilm formation could be enhanced in mopB mutants by addition of $\mathrm{Ca}$, it was still significantly reduced compared with WT. Ca concentrations of approximately $4 \mathrm{mM}$ in $4 \mathrm{Ca}$ media and Sap and $2 \mathrm{mM}$ in 50\% Sap are much higher than that of PD2 broth (approximately $0.02 \mathrm{mM}$ ) (Cobine et al. 2013), suggesting that $m o p B$ mutants may still be able to form biofilm in planta.
Biofilm formed by WT strains and the mopB mutants was increased under higher $\mathrm{Ca}$ concentration conditions. These results suggest that MopB is probably not the key protein responsible for Ca-induced increase in biofilm formation by $X$. fastidiosa. Interestingly, the effect of $m o p B$ deletion on reduced cell aggregation was compensated by adding $\mathrm{Ca}$ to the medium. In PD2 broth, the percentage of aggregated $m o p B$ mutant cells was less than that of WT strains, but $4 \mathrm{mM}$ Ca eliminated this difference. This suggests that Ca may be acting as an "ionic glue" at the surface, interacting with other surface proteins besides MopB. $\mathrm{Ca}$ is a divalent cation that can function as an ion bridge between negatively charged surfaces (such as bacteria) and therefore contributes to bacterial adhesion (Leite et al. 2002). Recently, it has been reported that $\mathrm{Ca}$ binding to extracellular DNA mediates bacterial aggregation in a variety of bacterial strains (Das et al. 2014), which could be another explanation for the observed effect.

Although MopB is not required for $\mathrm{Ca}$-induced increase in biofilm formation, this protein was shown here to be important for biofilm and disease development and fundamental for pili formation and, therefore, for twitching movement. Biofilm is important for $X$. fastidiosa inhabiting the xylem environment and the processes leading to disease development (Almeida et al. 2003; Chatterjee et al. 2008). Biofilm formation of this pathogen has been extensively studied, and a number of studies
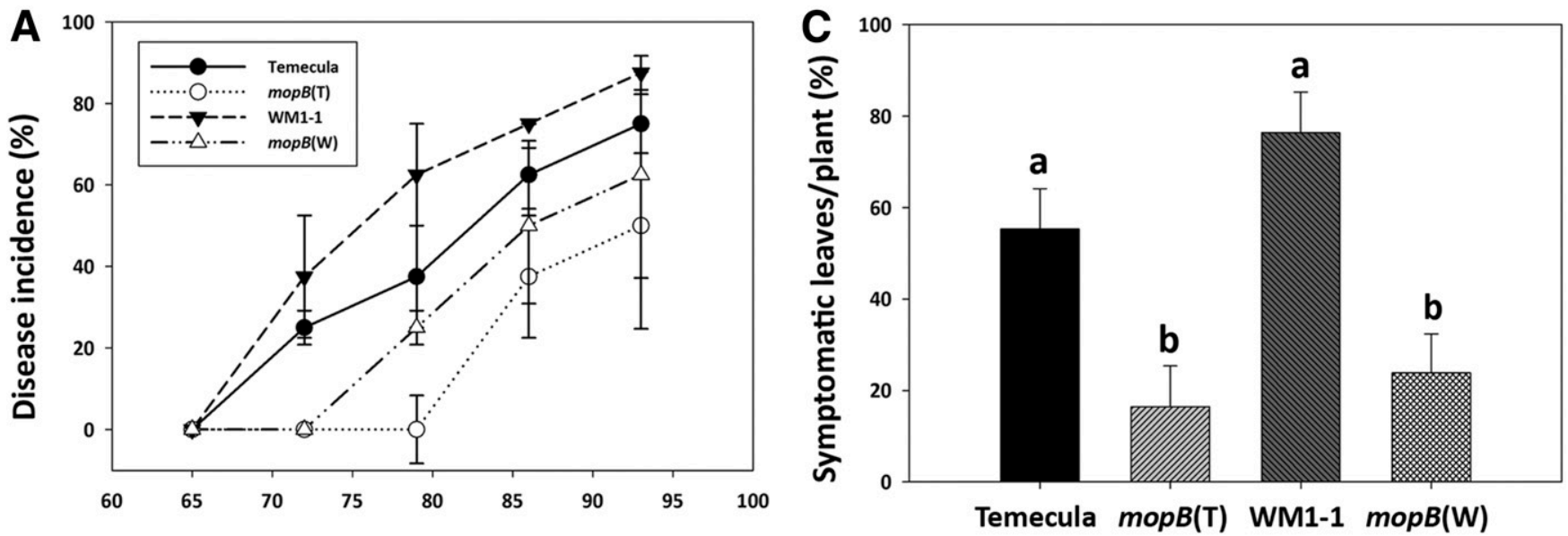

B

Time (days post inoculation)

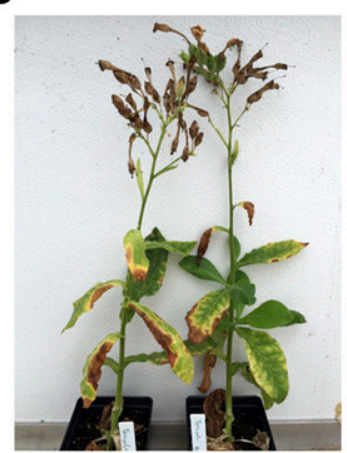

Temecula

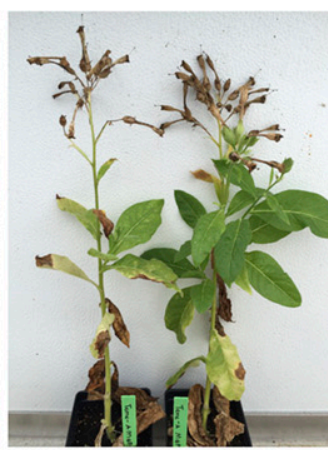

$\operatorname{mop} B(\mathrm{~T})$

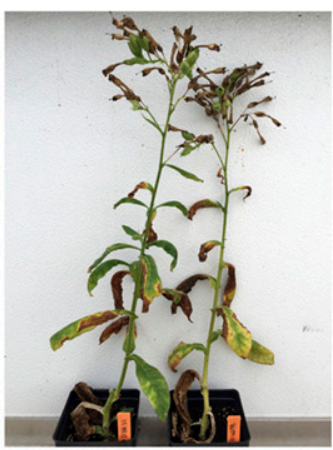

WM1-1

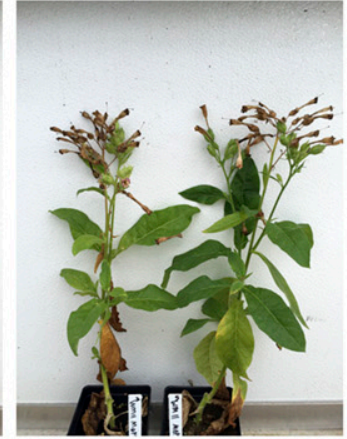

$\operatorname{mopB}(\mathrm{W})$

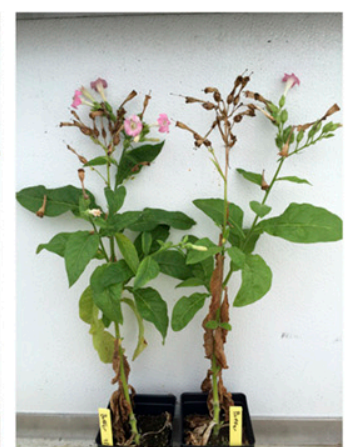

Buffer

Fig. 5. Virulence assessment of Xylella fastidiosa wild type (WT) strains and mopB mutants in tobacco plants in the greenhouse. A, Disease incidence in tobacco plant infected with $X$. fastidiosa. Symptom evaluation for each strain was performed during 4 weeks after the first leaf scorch symptoms were evident. Disease incidence is represented by the percentage of plants with symptoms among all eight inoculated plants. B, The mutation of mopB affected severity of symptoms in leaves. Photographs of tobacco plants were taken at 95 days postinoculation (dpi). C, Symptom quantification of plants inoculated with $X$. fastidiosa strains at 90 to 95 dpi. For each strain, the average percentage of symptomatic leaves showing marginal leaf scorch of an inoculated plant was represented in the graph. Each data point represents means $(n=24)$ and error bars correspond to standard error of the mean. Data were obtained from three independent experiments. Different letters on the bars indicate significant differences $(P<0.05)$, according to the GLIMMIX procedure using SAS 9.4 (SAS Institute Inc.). 
indicated that surface attachment and cell aggregation are important in the early stages of biofilm development (Cruz et al. 2012; Guilhabert and Kirkpatrick 2005). Our findings show that mopB deletion decreases the strength of the bacterial attachment to a surface and the percentage of aggregated cells, concomitantly affecting biofilm formation. OMPs are known to be important in biofilm formation, as demonstrated in previous studies using proteomic analysis, revealing that the major OMP OmpA is overexpressed during biofilm formation by Escherichia coli (Orme et al. 2006). A series of genetic studies showed that mutation of genes encoding OMPs affect biofilm production. In $E$. coli, deletion of ompA increases biofilm formation on hydrophobic surfaces and decreases biofilm formation on hydrophilic surfaces. This was shown to be related to cellulose synthesis, which responds to cell-surface stress and is regulated through the CpxRA stress response system (Ma and Wood 2009). OprF of Pseudomonas aeruginosa is homologous to OmpA of E. coli, deletion of oprF increased biofilm formation by $P$. aeruginosa. Absence of OprF caused cellenvelope stress that results in elevated levels of cyclic diguanylate monophosphate (c-di-GMP). The change of c-di-GMP in turn regulated Pel synthesis, affecting Pel-dependent phenotypes such as cell aggregation and biofilm formation (Bouffartigues et al. 2015). MopB has a similar structure to the OmpA family; therefore, MopB function may be similar to OmpA.

The phenotypic effects of mopB deletion may also be a consequence of cell-surface changes that directly or indirectly influence biofilm formation of $X$. fastidiosa. In this study, cellsurface structures, type I and type IV pili, were not observed at the pole of $m o p B$ mutant cells, using transmission electron microscopy. Transmission electron micrographs of one or both $X$. fastidiosa type I and IV pili-deficient strains have been presented in previous studies (Li et al. 2007; Meng et al. 2005). Compared with images presented in those papers, mopB mutants have similar morphologies to fimA and pilO double genedisrupted strain (DM12 mutant) with no pili. Consistent with our observations, ompA mutation in the E. coli $\mathrm{K} 1$ strain RS218 results in loss of type I fimbriae, which is part of the reason for decreased abilities of OmpA mutant to bind host cells (Teng et al. 2006). Twitching motility is an important factor for the virulence of $X$. fastidiosa (Burdman et al. 2011; Chatterjee et al. 2008), which occurs by the extension, tethering, and then, retraction of type IV pili (Mattick 2002). The colony fringe width and cell twitching motility speed (Fig. 3) demonstrated that $m o p B$ deletion caused loss of twitching motility. The biogenesis of type IV pili has been extensively studied in several bacteria, such as $P$. aeruginosa and Myxococcus xanthus. At least 12 proteins are involved in assembly of a single type IV pilus, and a number of other proteins are related with function and regulation of type IV pili (Burrows 2012; Craig and Li 2008). PilA, the basic structural unit of the type IV pilus filament, is secreted to the cell surface through the outer membrane secretory apparatus. The secretory apparatus consisted of the OMP PilQ and lipoprotein PilF (Burrows 2012; Craig and Li 2008). We propose that deficiency of MopB may affect the outer membrane integrity, then influence the structure or function, or both, of the outer membrane secretory apparatus that causes a defect on pilus biogenesis. MopB is the most abundant protein in the outer membrane of $X$. fastidiosa (Dandekar et al. 2012); therefore, its deficiency may affect membrane integrity. Chen et al. (2010) reported that absence of MopB in Xanthomonas campestris pv. campestris led to a less-compact outer membrane and a looser connection between inner and outer membranes. Moreover, a previous report (Belaaouaj et al. 2000) indicated that one of the mechanisms of neutrophil elastasemediated killing of $E$. coli is degradation of OmpA, leading to loss of membrane integrity.
In greenhouse experiments, Nicotiana tabacum was used as an experimental host of $X$. fastidiosa, instead of the natural host grapevine, to assess virulence of WT strains and mopB mutants. A series of studies established and improved the tobacco system for evaluating virulence of $X$. fastidiosa and investigating $X$. fastidiosa-host interactions (Alves et al. 2003; Francis et al. 2008; Lopes et al. 2000). These studies have shown that $N$. tabacum inoculated with PD-associated strains expressed leaf scorch and leaf cupping or curling symptoms (Oliver et al. 2014). The typical symptom, leaf scorch, in $N$. tabacum was similar to that in PD-affected grapevine (Francis et al. 2008). In addition, $X$. fastidiosa reisolated from symptomatic $N$. tabacum can cause PD symptoms in grapevine, including distinctive leaf scorch and typical 'match stick' (Francis et al. 2008). To evaluate virulence of $X$. fastidiosa PD strains, two aspects were considered: i) percentage of plants that exhibited leaf scorch and ii) percentage of scorched leaves in a symptomatic plant. Thus, strain virulence was established based on the severity and incidence of leaf scorch symptoms. A detailed symptoms evaluation standard for various $X$. fastidiosa strains in $N$. tabacum has been reported in a previously study (Oliver et al. 2014).

Homologs of mopB in the plant pathogen Xanthomonas campestris pv. campestris (Chen et al. 2010) and in the opportunistic pathogen Stenotrophomonas maltophilia (Chen et al. 2015) are required for pathogenesis. In our in-planta experiments, $\operatorname{mop} B$ mutants had reduced virulence in both $X$. fastidiosa strains. Deletion of mopB slowed disease development and reduced disease severity in tobacco plants. Using qPCR for bacterial population assessment, $\operatorname{mop} B$ deletion had no effect on $X$. fastidiosa population in the leaf petiole, showing that the mutants can still colonize the plants. Previous studies from our group indicated no correlation between the $X$. fastidiosa population size in petioles and symptom development in leaves (Oliver et al. 2014). Also, in the study of $X$. fastidiosa movement within grapevines, no significant difference in population size of $X$. fastidiosa between susceptible and resistant cultivars was detected in the petioles (Baccari and Lindow 2011). Given the high concentrations of $\mathrm{Ca}$ in xylem sap of tobacco (approximately $2.75 \mathrm{mM}$, unpublished), we speculate that biofilm would be partially restored and, therefore, the delayed symptoms are driven mainly by loss of twitching in these mutants.

Taken together, these results support the critical role of twitching in rapid development of disease symptoms caused by $X$. fastidiosa. In addition, our studies uncovered a role for MopB in both biofilm formation and twitching and therefore added mechanistic detail to the virulence mechanism and further supports use of MopB as a possible target for disease control. Although no clear role of MopB was found here in relation to the Ca response previously described in $X$. fastidios (Cruz et al. 2012), the EF-hand motif in the C-terminus of MopB that is predicted to be located in the periplasmic space may interact with $\mathrm{Ca}$ to perform other functions, therefore further experiments will be required to uncover the importance of the EF- hand motif in MopB.

\section{MATERIALS AND METHODS}

\section{Bacterial strains, plasmids, primers, and culture conditions.}

Bacterial strains and plasmids used in this study are listed in Table 1. All primers (Table 2) were designed by PrimerQuest software (Integrated DNA Technologies). X. fastidiosa type strain Temecula and a more aggressive strain, WM1-1 (Oliver et al. 2014; Parker et al. 2012), were used as the WT strains. All $X$. fastidiosa strains and mutants were cultured on PW or PD3 
plates (Davis et al. 1981) or PD2 broth (Davis et al. 1980) at $28^{\circ} \mathrm{C}$. All cell suspensions of $X$. fastidiosa used in this study were prepared as follows. The 7-day-old bacterial cultures were scraped from PW agar medium plates, were suspended in PD2 broth, and were diluted to an optical density at $600 \mathrm{~nm}\left(\mathrm{OD}_{600}\right)$ of 1.0. All E. coli strains were cultured on Luria-Bertani (LB) (Difco, BD Company) plates or in LB broth. To select transformants, $100 \mu \mathrm{g}$ of ampicillin and $50 \mu \mathrm{g}$ of kanamycin per liter were used.

\section{Identification of MopB in silico and construction of mutants.}

PD1709 was identified in silico using the BLASTP program from NCBI, using MopB from Xanthomonas campestris pv. campestris ATCC 33913 (accession number AAM40245) as a query and searching limited in $X$. fastidiosa.

Conserved domains were identified employing the Interpro program from the European Molecular Biology LaboratoryEuropean Bioinformatics Institute. Two-dimensional protein structure was predicted using the web-based PRED-TMBB software (Bagos et al. 2004).

Natural competence and homologous recombination were used to generate $X$. fastidiosa Temecula and WM1-1 mopB (PD1709) null mutants. The mopB mutant in Temecula was named $\operatorname{mop} B(\mathrm{~T})$ and in $\mathrm{WM} 1-1$ was named $\operatorname{mop} B(\mathrm{~W})$.

mopB knockout vectors. Genomic DNA of WT strain Temecula was extracted using a modified cetyltrimethylammonium bromide (CTAB) protocol (Doyle and Doyle
1987). For the construction of the mopB knockout vector, 800-bp upstream and downstream fragments flanking the $\operatorname{mop} B$ open reading frame were amplified by PCR with two primer pairs: mopB-U-F/mopB-U-R and mopB-D-F/mopB-D-R. AscI restriction site sequences were added to the $5^{\prime \prime}$ ends of mopBUP-R and mopB-D-F primers. The PCR products were digested with AscI and were ligated with T4 ligase (Thermo Fisher Scientific). The ligated product was cloned into pJET1.2/blunt cloning vector (Thermo Fisher Scientific). The resulting plasmid, pJET_mopB, was transformed into E. coli NEB 5- $\alpha$ (New England Biolabs), and positive clones were selected on a LB medium plate with ampicillin $(100 \mu \mathrm{g} / \mathrm{ml})$. A kanamycin cassette was amplified from pUC4K with primers containing the AscI restriction site sequence (Table 2). pJET_mopB was digested with $A s c$ I and was dephosphorylated with shrimp alkaline phosphatase (Affymetrix, USB). The kanamycin segment was also digested with $A s c \mathrm{I}$ and was ligated to the digested pJET_mopB by T4 ligase. The final plasmid pJET_mopB_Kan was transformed into $E$. coli NEB 5- $\alpha$, and positive clones were selected on an LB medium plate with kanamycin $(50 \mu \mathrm{g} / \mathrm{ml})$.

Transformation. mopB knockout vector pJET_mopB_Kan was transformed into $X$. fastidiosa Temecula and WM1-1 by taking advantage of the natural competence of the bacteria (Kandel et al. 2017; Kung and Almeida 2011). Briefly, pJET_mopB_Kan was transformed in E. coli EAM1 to allow in-vivo methylation of the plasmid (Matsumoto and Igo 2010). A 10- $\mu$ l cell suspension $\left(\mathrm{OD}_{600}=0.25\right)$ of WT strain was mixed with $5 \mu \mathrm{g}$ of methylated

Table 1. Strains and plasmids used in this study

\begin{tabular}{|c|c|c|}
\hline Strains and plasmids & Characteristics $^{\mathbf{a}}$ & Source \\
\hline Xylella fastidiosa Temecula & Wild-type Xylella fastidiosa & Van Sluys et al. 2003 \\
\hline Xylella fastidiosa WM1-1 & Wild-type $X$. fastidiosa & Parker et al. 2012 \\
\hline $\operatorname{mop} B(\mathrm{~T})$ & mopB mutant in $X$. fastidiosa Temecula, knockout in PD1709, $\mathrm{Km}^{\mathrm{R}}$ & This study \\
\hline $\operatorname{mop} B(\mathrm{~W})$ & mopB mutant in $X$. fastidiosa WM1-1, knockout in PD1709, $\mathrm{Km}^{\mathrm{R}}$ & This study \\
\hline Escherichia coli NEB $5-\alpha$ & $\begin{array}{l}\text { fhuA2 } \Delta(\arg F-\text { lacZ }) U 169 \text { phoA glnV44 } \$ 80 \Delta(\text { lacZ }) M 15 \text { gyrA96 recA1 } \\
\text { relA1 endA1 thi-1 hsdR17, general cloning host }\end{array}$ & New England Biolabs \\
\hline E. coli EAM1 & $\begin{array}{l}\mathrm{DH} 5 \alpha \text { derivative, } \mathrm{Sp}^{\mathrm{R}} \mathrm{St}^{\mathrm{R}} \text { attP } P_{\text {HKO22 }}:(\text { PLlacO-1-PD1607), expressing the } \\
\text { methylase (PD1607) of } X \text {. fastidiosa }\end{array}$ & Matsumoto and Igo 2010 \\
\hline pJET1.2 & Blunt cloning vector, $\mathrm{Amp}^{\mathrm{R}}$ & Thermo Fisher Scientific \\
\hline pJET_mopB & Regions upstream and downstream of mopB cloned into pJET1.2, $\mathrm{Amp}^{\mathrm{R}}$ & This study \\
\hline pJET_mopB_Kan & Kanamycin cassette cloned into Pjet_mopB, $\mathrm{Amp}^{\mathrm{R}}, \mathrm{Km}^{\mathrm{R}}$ & This study \\
\hline
\end{tabular}

${ }^{\mathrm{a}} \mathrm{Km}^{\mathrm{R}}, \mathrm{Amp}^{\mathrm{R}}, \mathrm{Sp}^{\mathrm{R}}$, and $\mathrm{St}^{\mathrm{R}}$ indicate resistance to kanamycin, ampicillin, spectinomycin, and streptomycin, respectively.

Table 2. Primers used in this study

\begin{tabular}{|c|c|c|c|}
\hline Primer & Function or target & Sequence $^{a}$ & Source \\
\hline \multicolumn{4}{|l|}{ Mutagenesis } \\
\hline mopB-U-F & Upstream торB & CGACCTTCTTTCGTATTCCTAG & This study \\
\hline mopB-U-R & Upstream торВ & ACGGGCGCGCCATGCTTGTCACATCCAGACAG & This study \\
\hline mopB-D-F & Downstream $m о р B$ & ACGGGCGCGCCGTAATGTGCTCCATAGCAAAGC & This study \\
\hline mopB-D-R & Downstream торB & ACC $\overline{A T T C C C T G G A A G A G T A G A ~}$ & This study \\
\hline KanAscIF & Kanamycin cassette & TTAGGCGCGCCGTCTGCCTCGTGAAG & This study \\
\hline KanAscIR & Kanamycin cassette & AAAGGCGCGCCAAGCCACGTTGTGT & This study \\
\hline \multicolumn{4}{|c|}{ Confirmation of mutations } \\
\hline mopBF & $m o p B$ gene deletion & GTCCGTGCTGAAGTAGCTTATC & This study \\
\hline mopBR & mор $B$ gene deletion & CAGGGTAGCGTCTCAAGATTTC & This study \\
\hline $\mathrm{KanF}$ & Kanamycin cassette replace & TCGGGAAGATGCGTGATCTG & This study \\
\hline KanR & Kanamycin cassette replace & CGCGATAATGTCGGGCAATC & This study \\
\hline B-U-F1 & Upstream mopB sequencing & CCTTCTTTCGTATTCCTAGACAAC & This study \\
\hline B-U-R1 & Upstream mopB sequencing & AGACAGCAGTCCCACAC & This study \\
\hline B-D-F1 & Downstream mopB sequencing & ACGCTGTAACGCATCTTCTATAC & This study \\
\hline B-D-R1 & Downstream торВ sequencing & ATATTCTCATATGCATTGA & This study \\
\hline B-UK-F & Kanamycin cassette sequencing & TGTGTGGGACTGCTGTCT & This study \\
\hline B-DK-R & Kanamycin cassette sequencing & ATTCACTGTCACCTCACATCG & This study \\
\hline \multicolumn{4}{|c|}{ Quantification of Xylella fastidiosa } \\
\hline HL5 & Detection of $X$. fastidiosa & AAGGCAATAAACGCGCACTA & Francis et al. 2006 \\
\hline HL6 & Detection of $X$. fastidiosa & GGTTTTGCTGACTGGCAACA & Francis et al. 2006 \\
\hline HLP & Detection of $X$. fastidiosa & FAM-TGGCAGGCAGCAACGATACGGCT-BHQ & Francis et al. 2006 \\
\hline
\end{tabular}

${ }^{a}$ AscI restriction site is underlined. 
pJET_mopB_Kan that was isolated from $E$. coli EAM1 and was spotted on a PD3 medium plate. After cells and DNA settled for an hour, the plates were incubated at $28^{\circ} \mathrm{C}$ for 3 days. The spot was scraped and was suspended in $250 \mu \mathrm{l}$ of PD2, and serial dilutions were made. Each dilution $(150 \mu \mathrm{l})$ was plated on a PW medium plate with kanamycin $(50 \mu \mathrm{g} / \mathrm{ml})$. Plates were incubated at $28^{\circ} \mathrm{C}$ until transformants were visible (approximately 10 days).

Confirmation of mopB null mutants. For DNA analysis, DNA was extracted from the resulting transformants in Temecula and WM1-1 backgrounds using the CTAB protocol mentioned above. Primer pairs mopBF/mopBR and KanF/KanR, designed from the $m o p B$ coding region and kanamycin cassette, were used to confirm the deletion of the mopB gene. Primer pairs mopB-U-F1/mopB-UR1, mopB-D-F1/mopB-D-R1, and B-UK-F/B-DK-R were used to sequence the homologous recombination region (Eurofins MWG Operon). Sequences were matched against the $X$. fastidiosa Temecula genome (GenBank), using BLAST to confirm the correct insertion of the kanamycin cassette and the absence of any sequence mismatches.

For SDS-PAGE and protein identification, $X$. fastidiosa strain was washed three times in cold TM buffer $(10 \mathrm{mM}$ Tris, $\mathrm{pH} 8.0$, containing $8 \mathrm{mM} \mathrm{MgSO}_{4}$ ) and was suspended in $5 \mathrm{ml}$ of fresh cold TM buffer (Chen et al. 2010). The suspension $\left(\mathrm{OD}_{600}=\right.$ $2.0)$ was sonicated by an ultrasonic cell disruptor. Bacterial proteins were separated by $12 \%$ SDS-PAGE, followed by staining of protein bands with Coomassie brilliant blue R-250 (Schagger 2006). The target protein band was excised from the gel and was subjected to liquid chromatography-tandem mass spectrometry (LC-MS/MS) analysis (Mass Spectrometry Core in Department of Chemistry and Biochemistry, Auburn University). Bands were identified using X!tandem (Fenyö and Beavis 2003) from the Global Protein Machine website.

\section{Planktonic growth and biofilm formation in media with different $\mathrm{Ca}$ concentrations.}

Planktonic growth and biofilm formation in 96-well plates was quantified according to methods previously described, with some modifications (Cruz et al. 2012). Briefly, in a 96-well plate, all wells were filled with $190 \mu$ l of either i) PD2 broth (PD2), which has a Ca concentration of approximately $0.02 \mathrm{mM}$ (Cobine et al. 2013), ii) PD2 broth supplemented with $4 \mathrm{mM} \mathrm{CaCl} 2$ (4Ca), which $\mathrm{Ca}$ concentration is very close to that of the grapevine xylem fluid (Cobine et al. 2013), iii) 50\% Sap (Vitis vinifera 'Chardonnay' grape xylem fluid mixed with an equal volume of PD2 broth), and iv) full-strength Sap. Grape sap was collected as previously described (Kandel et al. 2016). Four microtiter plates were included in each independent experiment. Ten microliters of cell suspension $\left(\mathrm{OD}_{600}=1.0\right)$ were inoculated in the $190 \mu \mathrm{l}$ of medium contained in each well. For each medium, each strain was inoculated in 12 wells, considered as repetitions. Uninoculated media were used as control. The four microtiter plates were incubated at $28^{\circ} \mathrm{C}$ and were shaken at $150 \mathrm{rpm}$ for 7 days. The $\mathrm{OD}_{600}$ values were recorded daily, which were considered as planktonic growth. On the seventh day, the planktonic phase was transferred to a new microtiter plate. The original plate was rinsed three times with sterile Milli-Q water. Biofilm was stained with $250 \mu \mathrm{l}$ of $0.1 \%$ crystal violet for $20 \mathrm{~min}$ and was rinsed with distilled water as described above. Then, $210 \mu \mathrm{l}$ of $6: 4$ ( $\mathrm{vol} / \mathrm{vol})$ acetone/ethanol was added and the plates were agitated at $150 \mathrm{rpm}$ for $5 \mathrm{~min}$. The $\mathrm{OD}_{600}$ of the resulting acetone/ethanol solution was measured. Three independent experiments were performed.

\section{Bacterial cell-cell aggregation analysis.}

The cell-cell aggregation assay was performed as previously described (Guilhabert and Kirkpatrick 2005). Cell suspension $\left(200 \mu \mathrm{l} ; \mathrm{OD}_{600}=1.0\right)$ was added into a $50-\mathrm{ml}$ conical tube filled with $10 \mathrm{ml}$ of PD2 broth or PD2 broth supplemented with $4 \mathrm{mM}$
$\mathrm{CaCl}_{2}$. Tubes were incubated at $28^{\circ} \mathrm{C}$ without shaking. Five days after incubation, all tubes were gently vortexed at low speed. After tubes were allowed to stand for $20 \mathrm{~min}$, the $\mathrm{OD}_{600}$ of supernatant $\left(\mathrm{OD}_{\mathrm{S}}\right)$ was measured. The supernatant was returned to the original tube, whole culture was homogenized vigorously by pipetting and $\mathrm{OD}_{600}\left(\mathrm{OD}_{\mathrm{t}}\right)$ was again measured. The relative percentage of aggregated cells was calculated using the formula: Cell aggregation rate $=\left[\left(\mathrm{OD}_{\mathrm{t}}-\mathrm{OD}_{\mathrm{S}}\right) \times 100\right] / \mathrm{OD}_{\mathrm{t}}$ (Burdman et al. 1998). Three replicates for each strain in each medium were used and two independent experiments were performed.

\section{Evaluation of surface attachment in microfluidic chambers.}

Adhesion force is a key parameter that reflects the strength of cell attachment to surfaces. This parameter was evaluated using microfluidic chambers, as previously described (Cruz et al. 2012; De La Fuente et al. 2007). The microfluidic chamber consists of a molded polydimethylsiloxane (PDMS) body and a glass microscope slide. There are two parallel microchannels $(80 \mu \mathrm{m}$ wide $\times 3.7 \mathrm{~cm}$ long $\times 50 \mu \mathrm{m}$ deep) on one surface of the PDMS body, and this surface was sealed with a glass slide. Two inlets and one outlet for each channel were used to allow media and bacterial suspension to enter the chamber separately and flow out together. The two channels can be simultaneously monitored under microscope.

$X$. fastidiosa Temecula and $m o p B(\mathrm{~T})$ were suspended in PD2 broth. A 5-ml glass syringe was filled with PD2 broth, while a 1-ml plastic syringe was filled with Temecula cell suspension. Both PD2 broth and Temecula cell suspension were introduced into one microchannel by two automatic syringe pumps (Pico Plus; Harvard Apparatus). Accordingly, PD2 broth and the mopB(T) cell suspension were introduced into a parallel and independent microchannel in the same chamber. The flow rate of PD2 broth and bacterial suspensions were also controlled by the syringe pumps. The microfluidic chambers were mounted onto a Nikon Eclipse Ti inverted microscope (Nikon) and were observed under a $40 \times$ objective, using Nomarski differential interference contrast optics and phase contrast. After the bacterial cells entered the channels, media flow speed was maintained at $0.25 \mu \mathrm{min}^{-1}$ for approximately $2 \mathrm{~h}$. When enough cells attached to the slide surface, media speed was adjusted to $1.0 \mu \mathrm{min}^{-1}$ for $1 \mathrm{~h}$ to remove nonattached cells. Media flow was then sequentially increased every $1 \mathrm{~min}$ by $10 \mu \mathrm{l} / \mathrm{min}$ from 1 to $160 \mu \mathrm{l} / \mathrm{min}$, to gradually remove attached cells. During this process, time-lapse microscopy images were acquired every $5 \mathrm{~s}$, using a Nikon DS-Q1 digital camera (Nikon) controlled by NIS-Elements Advanced Research 3.01(Nikon). The number of attached cells remaining in each frame was counted. Cell adhesion force was calculated as previously described (De La Fuente et al. 2007). Briefly, the fraction of the cells that detached from the chamber surface at each flow rate as a function of the drag force was plotted. Drag force is the total force exerted on the bacterium by flow (De La Fuente et al. 2007). Adhesion force of Temecula and $\operatorname{mop} B(\mathrm{~T})$ was calculated through integration of each curve that was plotted. Three independent microfluidic chamber experiments were performed.

\section{Quantification of twitching motility.}

Twitching motility of $X$. fastidiosa strains was evaluated on PW medium plate with different levels of $\mathrm{CaCl}_{2}$ supplementation (2 and $4 \mathrm{mM}$ ), as previously described (Cruz et al. 2012). For each strain, bacterial cells were spotted in quadruplicate on triplicate plates. After incubating at $28^{\circ} \mathrm{C}$ for 2 days, the peripheral fringe of each spot was observed under $40 \times$ phase-contrast optics on a Nikon Eclipse Ti inverted microscope (Nikon). The width of peripheral fringe was quantified using NIS-Elements Advanced Research 3.01 (Nikon). Three measurements were taken for each spot and three independent experiments were performed. 
The twitching speed of Temecula and $\operatorname{mop} B(\mathrm{~T})$ was assessed by microfluidic chamber, as previously described (Cruz et al. 2012; De La Fuente et al. 2007). Cell suspension of Temecula and $\operatorname{mop} B(\mathrm{~T})$ were separately introduced into different channels of the chamber. Media flow rate was controlled at $0.25 \mu \mathrm{l}$ $\mathrm{min}^{-1}$ for $2 \mathrm{~h}$ to allow cells attached on the surface. Time-lapse images were then acquired every $30 \mathrm{~s}$ for 2 or $3 \mathrm{~h}$ with a Nikon DS-Q1 digital camera. Using NIS-Elements Advanced Research 3.01, the upstream movement of bacterial cells was quantified according to their position frame by frame. Three independent experiments were performed.

\section{Transmission electron microscopy.}

$X$. fastidiosa strains were spread on PW medium plate for 2 days. Colonies were scraped and suspended in $200 \mu \mathrm{l}$ of distilled water. A 10- $\mu$ l cell suspension was deposited on Formvarcoated grids and was subsequently stained with $50 \mu \mathrm{l}$ of phosphotungstic acid. After 2 min, the excess liquid on the grids was removed, and the grids were air dried for $1 \mathrm{~min}$ and were observed on a Zeiss EM 10 transmission electron microscope (Carl Zeiss). Two independent experiments were performed.

\section{Greenhouse experiments.}

All $X$. fastidiosa strains were inoculated into tobacco plants (Nicotiana tabacum 'Petite Havana SR1', plant introduction number 552516) to evaluate their virulence, as previously described (De La Fuente et al. 2013). Seeds were provided by the United States Department of Agriculture Germplasm Resources Information Network. After seeds were germinated in SunshineH Mix \#8 (Sun Gro Horticulture Canada Ltd.), seedlings were transplanted in 4.5-in square pots and were grown in the greenhouse at 20 to $25^{\circ} \mathrm{C}$ with natural sunlight. Plants were watered regularly. Fertilizer (Peter's Professional 20-10-20 Peat-Lite Special; The Scotts Company) was applied one time at 40 to 45 days posttransplant. When tobacco plants had five to six true leaves, the top of the stem and the leaves were removed. The lowest three of the true leaves were kept and were inoculated with $X$. fastidiosa cells suspended in $1.5 \mathrm{ml}$ of succinate-citrate phosphate buffer $\left(\mathrm{OD}_{600}\right.$ of 1.0$)$ by a $1-\mathrm{ml}$ tuberculin syringe. Eight plants were inoculated for each $X$. fastidiosa strain, and eight control plants were only inoculated with buffer. Two independent experiments were performed.

Following inoculation, plants were grown in the greenhouse for two or three months, until leaf scorch symptom appeared. Plants symptoms were then assessed weekly for 4 weeks. Symptoms on leaves above the site where the stem was cut were recorded. Disease incidence was represented by the percentage of infected plants in the eight plants inoculated with the same strain.

To determine if inoculated plants became infected with $X$. fastidiosa, a qPCR analysis was performed as described previously (De La Fuente et al. 2013; Oliver et al. 2014). Briefly, leaves were collected at the end of the fourth week of symptom monitoring. For each strain, three infected plants were used for leaf collection. Four leaves above the inoculation point were collected from each plant and sections of the lower petiole were excised. Total DNA of the petioles was extracted using a modified CTAB protocol (Doyle and Doyle 1987) and $X$. fastidiosa CFU per gram of extracted petiole tissue was quantified, using qPCR and a standard curve as previously described (De La Fuente et al. 2013).

In addition, $X$. fastidiosa was isolated from infected plants, using a method described previously (Parker et al. 2012). Briefly, a short segment of infected plant stem was cut to tiny pieces after surface sterilization. The stem was soaked in PD2 broth at $28^{\circ} \mathrm{C}$ with shaking at $150 \mathrm{rpm}$ for $1 \mathrm{~h}$. The supernatant was diluted and was spread-plated on agar PW medium and PW with kanamycin $\left(50 \mu \mathrm{g} \mathrm{ml}^{-1}\right)$.

\section{Statistical analysis.}

Data from biofilm production in 96 -well plates, fringe width, and cell aggregation were analyzed by SAS 9.4 (SAS Institute Inc.) using GLIMMIX procedure, and means were separated by the Tukey-Kramer method $(P<0.05)$. To compare the difference of adhesion force, twitching motility speed, and the area under the disease progress curve between mutant and corresponding WT strain, data were analyzed by $t$ test $(P<0.05)$.

\section{ACKNOWLEDGMENTS}

We thank M. E. Miller, director of the Auburn University Research and Instrumentation Facility, for his help with transmission electron microscopy and the personnel of the Plant Science Research Center at Auburn University. We are also thankful to C. Arias and J. Coleman for helpful comments during the development of this research and M. Evans for help in the laboratory. This project was funded by Agriculture and Food Research Initiative competitive grant number 2015-67014-23085 from the United States Department of Agriculture National Institute of Food and Agriculture and the HATCH AAES (Alabama Agricultural Experiment Station) program.

\section{LITERATURE CITED}

Almeida, R. P., Newman, K. L., Purcell, A. H., and Lindow, S. E. 2003. Use of a green fluorescent strain for analysis of Xylella fastidiosa colonization of Vitis vinifera. Appl. Environ. Microbiol. 69:7319-7327.

Almeida, R. P. P., and Nunney, L. 2015. How do plant diseases caused by Xylella fastidiosa emerge? Plant Dis. 99:1457-1467.

Alves, E., Kitajima, E., and Leite, B. 2003. Interaction of Xylella fastidiosa with different cultivars of Nicotiana tabacum: A comparison of colonization patterns. J. Phytopathol. 151:500-506.

Arrizubieta, M. J., Toledo-Arana, A., Amorena, B., Penadés, J. R., and Lasa, I. 2004. Calcium inhibits bap-dependent multicellular behavior in Staphylococcus aureus. J. Bacteriol. 186:7490-7498.

Belaaouaj, A., Kim, K. S., and Shapiro, S. D. 2000. Degradation of outer membrane protein A in Escherichia coli killing by neutrophil elastase. Science 289:1185-1187.

Baccari, C., and Lindow, S. 2011. Assessment of the process of movement of Xylella fastidiosa within susceptible and resistant grape cultivars. Phytopathology 101:77-84

Bae, C., Han, S. W., Song, Y.-R., Kim, B.-Y., Lee, H.-J., Lee, J.-M., Yeam, I., Heu, S., and Oh, C.-S. 2015. Infection processes of xylem-colonizing pathogenic bacteria: Possible explanations for the scarcity of qualitative disease resistance genes against them in crops. Theor. Appl. Genet. 128:1219-1229.

Bagos, P. G., Liakopoulos, T. D., Spyropoulos, I. C., and Hamodrakas, S. J. 2004. PRED-TMBB: A web server for predicting the topology of $\beta$-barrel outer membrane proteins. Nucleic Acids Res. 32:W400-W404.

Bouffartigues, E., Moscoso, J. A., Duchesne, R., Rosay, T., FitoBoncompte, L., Gicquel, G., Maillot, O., Bénard, M., Bazire, A., and Brenner-Weiss, G. 2015. The absence of the Pseudomonas aeruginosa OprF protein leads to increased biofilm formation through variation in c-di-GMP level. Front. Microbiol. 6:630.

Burdman, S., Bahar, O., Parker, J. K., and De La Fuente, L. 2011. Involvement of type IV pili in pathogenicity of plant pathogenic bacteria. Genes (Basel) 2:706-735.

Burdman, S., Jurkevitch, E., Schwartsburd, B., Hampel, M., and Okon, Y. 1998. Aggregation in Azospirillum brasilense: Effects of chemical and physical factors and involvement of extracellular components. Microbiology 144:1989-1999.

Burrows, L. L. 2012. Pseudomonas aeruginosa twitching motility: Type IV pili in action. Annu. Rev. Microbiol. 66:493-520.

Castiblanco, L. F., and Sundin, G. W. 2015. New insights on molecular regulation of biofilm formation in plant-associated bacteria. J. Integr. Plant Biol. 58:362-372.

Chatterjee, S., Almeida, R. P., and Lindow, S. 2008. Living in two worlds: The plant and insect lifestyles of Xylella fastidiosa. Phytopathology 46:243.

Chen, Y.-Y., Wu, H.-C., Lin, J.-W., and Weng, S.-F. 2015. Functional properties of the major outer membrane protein in Stenotrophomonas maltophilia. J. Microbiol. 53:535-543.

Chen, Y.-Y., Wu, C.-H., Lin, J.-W., Weng, S.-F., and Tseng, Y.-H. 2010. Mutation of the gene encoding a major outer-membrane protein in Xanthomonas campestris pv. campestris causes pleiotropic effects, including loss of pathogenicity. Microbiology 156:2842-2854.

Cobine, P. A., Cruz, L. F., Navarrete, F., Duncan, D., Tygart, M., and De La Fuente, L. 2013. Xylella fastidiosa differentially accumulates 
mineral elements in biofilm and planktonic cells. PLoS One 8: e54936.

Craig, L., and Li, J. 2008. Type IV pili: Paradoxes in form and function. Curr. Opin. Struct. Biol. 18:267-277.

Cruz, L. F., Cobine, P. A., and De La Fuente, L. 2012. Calcium increases Xylella fastidiosa surface attachment, biofilm formation, and twitching motility. Appl. Environ. Microbiol. 78:1321-1331.

Cruz, L. F., Parker, J. K., Cobine, P. A., and De La Fuente, L. 2014. Calcium-enhanced twitching motility in Xylella fastidiosa is linked to a single PilY1 homolog. Appl. Environ. Microbiol. 80: 7176-7185.

Dandekar, A. M., Gouran, H., Ibáñez, A. M., Uratsu, S. L., Agüero, C. B., McFarland, S., Borhani, Y., Feldstein, P. A., Bruening, G., and Nascimento, R. 2012. An engineered innate immune defense protects grapevines from Pierce's disease. Proc. Natl. Acad. Sci. U.S.A. 109: 3721-3725.

Das, T., Sehar, S., Koop, L., Wong, Y. K., Ahmed, S., Siddiqui, K. S., and Manefield, M. 2014. Influence of calcium in extracellular DNA mediated bacterial aggregation and biofilm formation. PLoS One 9:e91935.

Davis, M., Purcell, A., and Thomson, S. 1980. Isolation media for the Pierce's disease bacterium. Phytopathology 70:425-429.

Davis, M. J., French, W. J., and Schaad, N. W. 1981. Axenic culture of the bacteria associated with phony disease of peach and plum leaf scald. Curr. Microbiol. 6:309-314.

De La Fuente, L., Montanes, E., Meng, Y., Li, Y., Burr, T. J., Hoch, H., and Wu, M. 2007. Assessing adhesion forces of type I and type IV pili of Xylella fastidiosa bacteria by use of a microfluidic flow chamber. Appl Environ. Microbiol. 73:2690-2696.

De La Fuente, L., Parker, J. K., Oliver, J. E., Granger, S., Brannen, P. M., van Santen, E., and Cobine, P. A. 2013. The bacterial pathogen Xylella fastidiosa affects the leaf ionome of plant hosts during infection. PLoS One 8:e62945.

Doyle, J., and Doyle, J. 1987. Genomic plant DNA preparation from fresh tissue-CTAB method. Phytochem. Bull. 19:11-15.

Fenyö, D., and Beavis, R. C. 2003. A method for assessing the statistical significance of mass spectrometry-based protein identifications using general scoring schemes. Anal. Chem. 75:768-774.

Francis, M., Civerolo, E., and Bruening, G. 2008. Improved bioassay of Xylella fastidiosa using Nicotiana tabacum cultivar SR1. Plant Dis. 92: 14-20.

Francis, M., Lin, H., Cabrera-La Rosa, J., Doddapaneni, H., and Civerolo, E. L. 2006. Genome-based PCR primers for specific and sensitive detection and quantification of Xylella fastidiosa. Eur. J. Plant Pathol. 115:203-213.

Guilhabert, M. R., and Kirkpatrick, B. C. 2005. Identification of Xylella fastidiosa antivirulence genes: Hemagglutinin adhesins contribute to $X$. fastidiosa biofilm maturation and colonization and attenuate virulence. Mol. Plant-Microbe Interact. 18:856-868.

Kandel, P. P., Lopez, S. M., Almeida, R. P., and De La Fuente, L. 2016. Natural competence of Xylella fastidiosa occurs at a high frequency inside microfluidic chambers mimicking the bacterium's natural habitats. Appl. Environ. Microbiol. 82:5269-5277.

Kandel, P. P., Almeida, R. P. P., Cobine, P. A., and De La Fuente, L. 2017. Natural competence rates are variable among Xylella fastidiosa strains and homologous recombination occurs in vitro between subspecies fastidiosa and multiplex. Mol. Plant-Microbe Interact. 30:589-600.

Koebnik, R., Locher, K. P., and Van Gelder, P. 2000. Structure and function of bacterial outer membrane proteins: Barrels in a nutshell. Mol. Microbiol. 37:239-253

Kung, S. H., and Almeida, R. P. 2011. Natural competence and recombination in the plant pathogen Xylella fastidiosa. Appl. Environ. Microbiol. 77:5278-5284.

Leite, B., Ishida, M., Alves, E., Carrer, H., Pascholati, S., and Kitajima, E. 2002. Genomics and X-ray microanalysis indicate that $\mathrm{Ca}^{2+}$ and thiols mediate the aggregation and adhesion of Xylella fastidiosa. Braz. J. Med. Biol. Res. 35:645-650.

Li, Y., Hao, G., Galvani, C. D., Meng, Y., De La Fuente, L., Hoch, H., and Burr, T. J. 2007. Type I and type IV pili of Xylella fastidiosa affect twitching motility, biofilm formation and cell-cell aggregation. Microbiology 153:719-726.

Lopes, S., Ribeiro, D., Roberto, P., Franca, S., and Santos, J. 2000 Nicotiana tabacum as an experimental host for the study of plant-Xylella fastidiosa interactions. Plant Dis. 84:827-830.

Ma, Q., and Wood, T. K. 2009. OmpA influences Escherichia coli biofilm formation by repressing cellulose production through the CpxRA twocomponent system. Environ. Microbiol. 11:2735-2746.
Matsumoto, A., and Igo, M. M. 2010. Species-specific type II restrictionmodification system of Xylella fastidiosa Temecula1. Appl. Environ. Microbiol. 76:4092-4095.

Mattick, J. S. 2002. Type IV pili and twitching motility. Appl. Environ. Microbiol. 56:289-314.

Meng, Y., Li, Y., Galvani, C. D., Hao, G., Turner, J. N., Burr, T. J., and Hoch, H. 2005. Upstream migration of Xylella fastidiosa via pilus-driven twitching motility. J. Bacteriol. 187:5560-5567.

Nascimento, R., Gouran, H., Chakraborty, S., Gillespie, H. W., AlmeidaSouza, H. O., Tu, A., Rao, B. J., Feldstein, P. A., Bruening, G., and Goulart, L. R. 2016. The type II secreted lipase/esterase LesA is a key virulence factor required for Xylella fastidiosa pathogenesis in grapevines. Sci. Rep. 6:18598.

Navarrete, F., and De La Fuente, L. 2014. Response of Xylella fastidiosa to zinc: Decreased culturability, increased exopolysaccharide production, and formation of resilient biofilms under flow conditions. Appl. Environ. Microbiol. 80:1097-1107.

Oliver, J., Sefick, S., Parker, J., Arnold, T., Cobine, P., and De La Fuente, L. 2014. Ionome changes in Xylella fastidiosa-infected Nicotiana tabacum correlate with virulence and discriminate between subspecies of bacterial isolates. Mol. Plant-Microbe Interact. 27:1048-1058.

Orme, R., Douglas, C., Rimmer, S., and Webb, M. 2006. Proteomic analysis of Escherichia coli biofilms reveals the overexpression of the outer membrane protein OmpA. Proteomics 6:4269-4277.

Parker, J. K., Havird, J. C., and De La Fuente, L. 2012. Differentiation of Xylella fastidiosa strains via multilocus sequence analysis of environmentally mediated genes (MLSA-E). Appl. Environ. Microbiol. 78:1385-1396.

Parker, J. K., Chen, H., McCarty, S. E., Liu, L. Y., and De La Fuente, L. 2016. Calcium transcriptionally regulates the biofilm machinery of Xylella fastidiosa to promote continued biofilm development in batch cultures. Environ. Microbiol. 18:1620-1634.

Roper, M. C., Greve, L. C., Warren, J. G., Labavitch, J. M., and Kirkpatrick, B. C. 2007. Xylella fastidiosa requires polygalacturonase for colonization and pathogenicity in Vitis vinifera grapevines. Mol. Plant-Microbe Interact. 20:411-419.

Ruiz, N., Kahne, D., and Silhavy, T. J. 2006. Advances in understanding bacterial outer-membrane biogenesis. Nat. Rev. Microbiol. 4:57-66.

Sarkisova, S. A., Lotlikar, S. R., Guragain, M., Kubat, R., Cloud, J., Franklin, M. J., and Patrauchan, M. A. 2014. A Pseudomonas aeruginosa EF-hand protein, EfhP (PA4107), modulates stress responses and virulence at high calcium concentration. PLoS One 9:e98985.

Schagger, H. 2006. Tricine-SDS-PAGE. Nat. Protoc. 1:16-22.

Shi, X. Y., Dumenyo, C. K., Hernandez-Martinez, R., Azad, H., and Cooksey, D. A. 2007. Characterization of regulatory pathways in Xylella fastidiosa: Genes and phenotypes controlled by algU. Appl. Environ. Microbiol. 73:6748-6756.

Sun, Q., Sun, Y., Walker, M. A., and Labavitch, J. M. 2013. Vascular occlusions in grapevines with Pierce's disease make disease symptom development worse. Plant Physiol. 161:1529-1541.

Teng, C.-H., Xie, Y., Shin, S., Di Cello, F., Paul-Satyaseela, M., Cai, M., and Kim, K. S. 2006. Effects of ompA deletion on expression of type 1 fimbriae in Escherichia coli $\mathrm{K} 1$ strain RS218 and on the association of $E$. coli with human brain microvascular endothelial cells. Infect. Immun. 74:5609-5616.

Van Sluys, M., De Oliveira, M., Monteiro-Vitorello, C., Miyaki, C., Furlan, L., Camargo, L., Da Silva, A., Moon, D., Takita, M., and Lemos, E. 2003. Comparative analyses of the complete genome sequences of Pierce's disease and citrus variegated chlorosis strains of Xylella fastidiosa. J. Bacteriol. 185:1018-1026.

Voegel, T. M., Doddapaneni, H., Cheng, D. W., Lin, H., Stenger, D. C. Kirkpatrick, B. C., and Roper, M. C. 2013. Identification of a response regulator involved in surface attachment, cell-cell aggregation, exopolysaccharide production and virulence in the plant pathogen Xylella fastidiosa. Mol. Plant Pathol. 14:256-264.

Zhang, S., Chakrabarty, P. K., Fleites, L. A., Rayside, P. A., Hopkins, D. L., and Gabriel, D. W. 2015. Three new Pierce's disease pathogenicity effectors identified using Xylella fastidiosa biocontrol strain EB92-1. PLoS One 10:e0133796.

\section{AUTHOR-RECOMMENDED INTERNET RESOURCES}

European Molecular Biology Laboratory-European Bioinformatics Institute Interpro program: https://www.ebi.ac.uk/interpro NCBI BLASTP program: https://blast.ncbi.nlm.nih.gov/Blast.cgi PRED-TMBB server: http://bioinformatics.biol.uoa.gr/PRED-TMBB 